\title{
The Diverse Implications of EU Instruments for Legal Criminality of Political Reforms in Macedonia and Albania
}

\author{
Prof .Dr. Ismail Zejneli \\ Prof Dr Dean of Low Faculty, SEEU University Tetova Macedonia \\ E-mail: i.zejneli@seeu.edu.mk
}

Prof Ass Dr. Alba Robert Dumi

Prof .Ass Dr, Dean of Graduated School"Ismail Qemali" Vlora University Albania, Management Department, Economy Faculty, Tirana University

Email:alba.besi12@gmail.com

\section{Doi:10.5901/mjss.2013.v4n9p253}

\section{Abstract}

After a period of relative stagnation, the past few months witnessed the adoption of a plethora of legislative instruments under the third pillar. These instruments can be seen as the third wave of third-pillar law, following the wave of measures adopted post-Maastricht and the second wave of measures adopted post-Amsterdam and Tampere. The third wave of third-pillar law extends to most major areas of European integration in criminal law. New legislation involves the harmonization of substantive criminal law (including the terrorism, organized crime and racism and xenophobia), mutual recognition (with measures such as the European Evidence Warrant and legislation on the recognition of probation decisions and the transfer of sentenced persons), the work of EU criminal justice bodies such as Europol and Euro just, and the development of standards to regulate the proliferation of third pillar mechanisms to collect, analyze and exchange personal data. By analyzing the background and content of these instruments, this article will assess their impact on the future development of EU criminal law and justice. As a very dangerous form that damage the economies of states, without a doubt considered and economic criminality, which caused by economic criminal action taken, as actions that impede business between business entities. All of these actions are considered as unlawful actions.

Keywords: Economic criminality, Firm wide risk, Economy \& Production, Activities Products and markets, EU financing reforms, EU standards.

JEL Clasification: K0, K13, K14, K19, K34, K35, K41

\begin{abstract}
"We live in a world that holds brighter prospects but also greater threats than we have known. The future will depend partly on our actions. We need both to think globally and to act locally. To defend its security and to promote its values, the EU has strategic objectives: Addressing the Threats: The European Union has been active in tackling the key threats. It has responded after 11 September with measures that included the adoption of a European Strategy, steps to attack terrorist financing and an agreement on mutual legal assistance with the U.S.A. The EU continues to develop cooperation in this area and to improve its defense. (EU strategic rep 2011, pp 3)
\end{abstract}

\section{Introduction}

\subsection{Organized crime the definition and legal-concept}

In the field of organized crime, EU legislation aimed at harmonizing substantive criminal law first appeared in 1998 in the form of a third pillar Joint Action "on making it a criminal offence to participate in a criminal organisation in the European Union".24 The Joint Action provided an ambitious attempt to define organised crime groups, taking into account law enforcement perceptions, and criminalised active participation in such Actions,which are not based in work and other permitted activities but in misuse, frauds and suspicious transactions. (Lickett 2012)Criminality as a negative phenomenon and dangerous to society manifested in various forms throughout the course of human history. 


\subsubsection{Vision of this paper research}

The strategy's vision in this paper research is: To facilitate access, for people with disabilities, to the appropriate range of housing and related support services, delivered in an integrated and sustainable manner, which promotes equality of opportunity, individual choice and independent living.

\subsubsection{Strategic Aims of this paper research:}

The strategy has strategic aims:

1. To promote and mainstream equality of access for people with a disability to the full-range of housing options available suited to individual and household need.

2. To develop national protocols and frameworks for effective interagency cooperation which will-facilitate personcentred delivery of housing and relevant support services.

3. To support people with a disability to live independently in their own homes and communities, where appropriate.

\subsubsection{Strengthening the rule of law and democratic governance}

"Economic criminality" submitted in all areas of economic activity, ranging from the business of deposit, through production, cash business, commercial sector, foreign trade, commercial shops and hotel, accountants and economic sectors until in the general leadership. Strengthening the rule of law and democratic governance is central to the enlargement process.

This underpins and further promotes stability in a region recently scarred by conflict and supports the creation of an environment in south-east Europe conducive to growth and attracting investment, increased regional cooperation and dealing with common challenges such as the fight against organised crime and corruption. It addresses issues of direct concern to citizens in both the EU and the enlargement countries of justice, security and fundamental rights. With the Council's endorsement in June of the Commission's proposed new approach to judiciary and fundamental rights and justice, freedom and security as part of the negotiating framework for Montenegro, the rule of law is firmly anchored at the heart of the accession process, laying the foundation also for future negotiations. These illegal actions of physical and legal persons who are exercising a business activity or in any way are related to the business, and essentially dealing with criminal acts performed in the economy make up economy crime.

All these actions are undertaken for the purpose of material and financial benefits. The difficulties in dealing with economic criminality begin straight away when we attempt to find a blanket definition for it. No one has yet been able to do so satisfactorily: "Although economic criminality and the combating thereof is one of the most pressing issues of the present day, its definition and the definition of what constitutes an economic crime remains one of the unsolved problems..." Astonishing though that may seem, it is indeed the case. Economic criminality encompasses all crimes that are committed within, against and by business enterprises. While this includes crimes committed by employees, it is important to realize that employee criminality is only one facet of economic criminality.

\subsubsection{Strategy and advertise effectively}

Develop flyers, posters, and letters or e-mails with information about activities, including the date and time, location, how to participate, and how activities are relevant or helpful for intended participants. Adapt program content to increase accessibility for people with disabilities. Addressing risks of instability in the Western Balkans is manifestly in our joint interest, given the legacy of war and division which has plagued this region. The enlargement process supports the advocates of reform in the region, further entrenching its post-war democratic transition. It helps avoid the potentially far higher costs of dealing with the consequences of instability. Strengthening stability and democracy in south-east Europe is also an investment in deep and sustainable democracy in the EU's wider neighbourhood.

\section{Economy criminality and definitions}

\subsection{Organised Crime, data gathering from EU members states.}

Europe is a prime target for organised crime. This internal threat to our security has an important external dimension: 
cross-border trafficking in drugs, women, illegal migrants and weapons accounts for a large part of the activities of criminal gangs. It can have links with terrorism. The impact of the move to the first pillar on state sovereignty and the ability of Member States to dictate domestic criminal justice policy, made crystal-clear in the case of ship-source pollution. Three EU Member States, Greece, Cyprus and Malta all have major shipping interests and have lobbied against tough criminal sanctions on ship-source pollution.

While this veto might have influenced negotiations also on the original first-pillar Directive (negotiated in parallel with the third-pillar Framework Decision87), this is no longer the case after the ECJ judgment, which has triggered negotiations for a firstpillar criminal law Directive As one of the best definitions of economic criminality considered definition of Edwin Sutherlandit (President of the American Association for Sociology) by 1939 which this criminality is considered as white collar criminality. According to him economic criminality considered as criminality which appears in the sphere of economic activity, which forms mostly manifested during the acquisition of shares, advertising of goods, coverage of financial and corruption of civil servants directly or indirectly.(See too; B.Banoviq, obezbegjenje dokaza was kriminalistickoj obradi krivicni dela privrednog kriminaliteta, Belgrade, 2002, p.13.)

\subsection{Research out to the community}

H1. The renewed consensus on enlargement, agreed by the European Council, remains the basis for the EU's enlargement policy.

This policy is based on the principles of consolidation of commitments, fair and rigorous conditionality and good communication with the public, combined with the EU's capacity to integrate new members.

H2. The current enlargement agenda covers the Western Balkans, Turkey and Iceland. The EU has consistently proclaimed the inclusiveness of its policy towards the Western Balkans, with successive European Councils confirming that the future of the whole region lies within the EU.

H3. The Stabilisation and Association process remains the common framework for the necessary preparations.Basic causes that condition the appearance of this type of criminality are: report form of the property of the organization working, forms of property, the degree of concentration of functions, the development and justification defense system, the organization's business position working, governance and organization development professional and intellectual ability of the offender. The Commission has a point in criticising the maintenance in a harmonisation measure of two alternative options of criminalisation of organised crime.

The current enlargement agenda covers the Western Balkans

The successive European Councils

The Stabilisation and Association process

Source: B.Banoviq, obezbegjenje dokaza was kriminalistickoj obradi krivicni dela privrednog kriminaliteta, Belgrade, 2002, p.13.)

This does not help towards legal certainty and creates a potentially very extensive scope of criminalisation of organised crime across the European Union. This is linked to the fact that both alternative offences are drafted in very broad terms-the concept of a criminal organisation is very broad and vague and conspiracy does not have to involve the actual execution of a criminal activity. Although the objective factors have central importance in terms of appearance and the structure conditionality certain economic criminality, professionalism and intellectual ability, as subjective factors, in certain cases, may be crucial in committing economic criminality offenses."Perpetrators of crimes against the economy may appear different persons, in some cases economic offenses carry all persons, while some illegal works in the field of economy can perform only one category of persons. Associated with guilt, such offenses may be committed intentionally, which must include the desire of offender for his work. In some offenses against the economy is foreseen and the receipt of the items with which the offenses was committed (see Section 244 KP Kosovo, counterfeit money). 


\subsubsection{Macedonia and an overview in criminal actions field}

Slow changes in Macedonia after independence have resulted with massive filing criminal actions which have not been known until then. This particular phenomenon has been evident during the process of transformation of state-owned enterprises into private. In this process by exploiting the situation of termination of these enterprises with state capital which enterprises created the situation that they have huge debts and using these situations to these enterprises necessarily should start a bankruptcy procedure.

By utilizing these situations, these companies were bought very cheap, while in such purchases was created a certain layer of excluded from work that called as bankruptcy worker. There have been a number of positive developments in the enlargement countries over the past year. In addition to those concerning Croatia, Montenegro and Serbia, positive results have been achieved in the former, Yugoslav Republic of Macedonia, where the High Level Accession Dialogue has led to a sharper focus on reforms by the authorities.Dialogue between government and opposition in Albania has allowed the political stalemate to be largely overcome with the adoption of electoral and parliamentary reforms. Accession negotiations with Iceland are progressing well.

Turkey has shown active support of the new positive agenda announced last year and launched by the Commission in May 2012. These situations have caused to ascertain that in the Republic of Macedonia as the dominant form of economic criminality be considered transformation of state-owned enterprises to the private, causing false bankruptcies, tax evasion, illegal transactions in the area of payment turnover, fraud of committees during their savings, maintain double accounting in order to remove corruption etc.

During the transition period, specifically during the years 2002-2010, economic criminality situation in the Republic of Macedonia was as follows;

\begin{tabular}{|l|c|c|c|c|c|c|c|c|c|}
\hline & $\mathbf{2 0 0 2}$ & $\mathbf{2 0 0 3}$ & $\mathbf{2 0 0 4}$ & $\mathbf{2 0 0 5}$ & $\mathbf{2 0 0 6}$ & $\mathbf{2 0 0 7}$ & $\mathbf{2 0 0 8}$ & $\mathbf{2 0 0 9}$ & $\mathbf{2 0 1 0}$ \\
\hline $\begin{array}{l}\text { Misuse of official duty and } \\
\text { authorizations }\end{array}$ & 178 & 854 & 504 & 275 & 291 & 477 & 367 & 290 & 246 \\
\hline Hiding of tax & 84 & 109 & 96 & 114 & 35 & 40 & 67 & 54 & 50 \\
\hline $\begin{array}{l}\text { Damage and unauthorized } \\
\text { access to a computer system }\end{array}$ & 2 & 1 & 7 & 2 & 2 & 7 & 20 & 63 & 36 \\
\hline Fraud in obtaining credit & 2 & 3 & 1 & 28 & 10 & 25 & 88 & 67 & 74 \\
\hline
\end{tabular}

From the above table we will see that offenses against public finances, circulation of payment and the economy from year to year is increased starting in 2004 to 2007, where later we will see that during the years 2009 and 2010 there is a slight decrease. In 2010, for committing offenses against public finances, payment circulation and the economy are presented 620 adult persons, of whom; 558 persons known perpetrator,78 female offenders, to 60 persons is thrown application, for 60 persons is interrupted further investigation, to 11 persons investigation is terminated, for 439 perpetrators is indicted and 62 perpetrators are unknown. (I.Zejneli 2007)

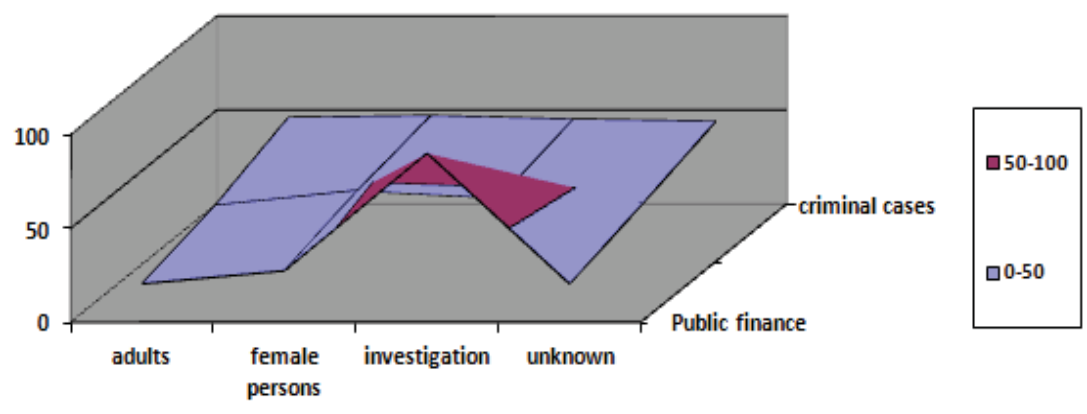

Tab 1: Economic criminality situation in the Republic of Macedonia on years 2002-2010

\subsection{Juridical-penal treatment and economic sphere of development}

In the spirit of good neighbourly relations, open bilateral issues need to be addressed by the parties concerned as early 
as possible during the enlargement process, with determination, taking into account the overall EU interests. There has been little progress on such issues over the past year. The Commission urges parties to make every effort towards solving outstanding disputes in line with established principles and means, including referring issues as appropriate to the International Court of Justice or other existing or ad hoc dispute settlement bodies. Bilateral issues should not hold up the accession process. The Commission stands ready to facilitate the creation of the necessary political impetus in the search for solutions and to support related initiatives. (I.Zejneli 2007)

The border arbitration agreement between Slovenia and Croatia, the implementation of which began in the course of 2012, paves the way for solving this bilateral issue and is a good example of the way forward.The Commission underlines the importance of Croatia's declaration on promoting European values in South-East Europe and in particular Croatia's commitment that bilateral issues should not obstruct the accession process of candidate countries. As regards the Yugoslav Republic of Macedonia, the Commission underlines that a negotiated and mutually acceptable solution, under the auspices of the UN, to the dispute over the name of the country remains essential.

Negotiated and mutually acceptable solution

The principle of freedom

The establishment of business entities

Source: CPC Article 364 Commentary of Criminal Procedure; Halim Islam, Artan Hoxha \& llir Panda, Tirana 2003, p. 48

This insurance is done by foreseen and sanctioning criminal actions directed against the public finances, payment circulation and the economy as a separate criminal offense in Criminal Code of Macedonia. This way of providing economic system is based on the so-called criminal legal protection. In 2008, out of a total of 15462 known perpetrators of criminal offenses, 542 have been the perpetrator of this crime. The largest number of perpetrators,(232) are from Skopje. Of this number 21 were juvenile offenders as persons aged 14 to 18 years. A solution needs to be found without further delay. State to be able to carry out its powers in the economic sphere in terms of the existence of private property as the dominant form of ownership, in which is based on the principle of freedom of establishment of business entities, there is a need for ensuring the implementation of state bodies powers in this area.

\section{Literature Review and Hypotheses}

The Yugoslav Republic of Macedonia was granted candidate status in 2005. In 2009, the Commission assessed that the country sufficiently met the political criteria and recommended the opening of negotiations. This recommendation was reiterated by the Commission in 2010 and 2011 and now in 2012. The Commission strongly believes that moving the accession process of this country to its next stage is necessary in order to consolidate the pace and sustainability of reforms, in particular as regards the rule of law, as well as to strengthen inter-ethnic relations. The region as a whole would benefit. Economic criminality as very dangerous phenomenon is sanctioned and criminal and legal provisions. Criminal codes of various countries have provided separate chapters which treats this type of crime. (I.Zejneli 2007)

Some of the offenses against the public finances, payment circulation and the economy by KP Macedonia are: Counterfeit Money (n.268.i KP); money laundering and illegal material benefit (n.273 KP); unauthorized production (n.276 KP); contraband (n.278 KP); violation of equality in the exercise of economic activity (n.282 KP); unauthorized use of a foreign firm (n.285 KP). With the Yugoslav Republic of Macedonia, a High Level Accession Dialogue (HLAD) was launched in March 2012 in Skopje. The HLAD put EU integration to the forefront of the domestic agenda, giving it a new boost by ensuring a structured, high level discussion on the main reform challenges and opportunities. The key issues include freedom of expression, rule of law and ethnic relations, challenges for electoral reform, public administration reform, strengthening of the market economy and good neighbourly relations. The Government is making progress addressing the ambitious reform targets included in its roadmap defining the specific measures and time frame for their delivery. 


\subsection{Gathering data for Literature Review}

Criminal Code of the Republic of Albania, based on the statement of the UN, for the fight against corruption and swag, in December 1996, nr.9275 Law, dated 16.09.2004, especially the in Convention on corruption, Council of Europe, date 27.Janar 1999, devotes a number of provisions-articles, against crime of corruption- active and passive corruption in the private sector, active and passive corruption of public officials, of high state and local elected officials, judges and prosecutors and other justice officials, witnesses, experts and interpreters and the exercise of unlawful influence on persons exercising public functions.

In money laundering is intended to be hiding and not the legality and use of revenue sources,that results from these sources for specific purposes legalizing illegal income). Fraud represents the essence of all the action in money laundering, because during all actions is intended that certain tools to be shown as legal in order they can be into circulation.

In progress through the table will present data on persons accused of committing a criminal offense of money laundering, for the years 2006-2010.

\begin{tabular}{|l|c|c|c|c|c|}
\hline & $\mathbf{2 0 0 6}$ & $\mathbf{2 0 0 7}$ & $\mathbf{2 0 0 8}$ & $\mathbf{2 0 0 9}$ & $\mathbf{2 0 1 0}$ \\
\hline Convicted persons & 1 & 2 & 19 & 1 & 1 \\
\hline Women & - & 2 & - & - & - \\
\hline Persons found guilty & - & 1 & 1 & 1 & - \\
\hline Procedure was terminated & - & 1 & - & - & 1 \\
\hline
\end{tabular}

From the total number of persons charged with criminal offenses of money laundering for the period in question, the court has decided as follows:

\begin{tabular}{|l|c|c|c|c|c|}
\hline & $\mathbf{2 0 0 6}$ & $\mathbf{2 0 0 7}$ & $\mathbf{2 0 0 8}$ & $\mathbf{2 0 0 9}$ & $\mathbf{2 0 1 0}$ \\
\hline Convicted persons & - & 1 & 19 & 1 & - \\
\hline Women & - & 1 & 5 & - & - \\
\hline Total penalties & - & 1 & 9 & - & - \\
\hline Prison sentence & - & 1 & 9 & - & - \\
\hline Alternative measures & & -- & 10 & - & - \\
\hline Suspended sentence & & -- & 10 & 1 & - \\
\hline
\end{tabular}

From the above table we will see that during the period in question, for a criminal offense of money laundering have been convicted of a total of 21 , persons of whom the most in 2008,19 people. Also we will see that the perpetrators of this crime appear persons of both sexes.

\subsection{Albania and problems identified.}

In the context of criminality in Albania we will focus on a specific aspect for Albania. Any anticipated strategy should also take into account the level of payment and other benefits of the staff within the justice system in general and judges in particular. An appropriate level of pay and other benefits is probably one of the most effective ways to "immunize" employees from corruption.

\subsubsection{The Constitution of the Republic of Albania.}

Offenses against the person are the worse wound crime in Albania. This is because these offenses are committed against individuals Albanian society "Offenses against the person recorded 2240 proceedings, or compared to 2002, decreasing 5.5\%. (Sollaku Th 2006 report pp 4)

Although generally results in a decreasing trend of these criminal group, is evidenced an increasing number: 63 proceedings for murder, article 76 of the Penal Code. These crimes have significant consequences to life and health 
such as the death of 271 persons and serious or slight injury of 421 persons. Of these criminal proceedings were sent for judgment, judgment and convicted 863 defendants and 642 other defendants judgment continues.For these types of serious crimes the prosecution has sought the prosecution of a fierce political and judgment proceedings, to influence in alleviation and prevent this phenomenon very negative, with serious consequences not only for the victims and their families, but also for the public safety of society as a whole (Sollaku Th 2006 report pp 7, 11, 21).

\subsection{Albanian judicial system and the need for reform.}

Albanian judicial system has undergone radical changes and a improved considerably over the last decade. However, the need for more legitimacy and control show that the Albanian legal system needs further improvement in order to create a stable and transparent system, based on the principles of the rule of law. Legal instrumental often not respected or abused in order to achieve results "desired" - but not necessarily legitimate. Consequently, the rights and freedoms of individuals often violated and give the impression that the judicial system is neither fair nor independent. (Law no. 8436, dated December 28, 1998, "On the organization of the judicial power in the Republic of Albania" [Judicial Power Law], Article 39, paragraph 1.

\subsubsection{The specific data for types of economic criminality}

For illegal trafficking are followed 270 proceedings, with 327 defendants. For the cultivation and trafficking of narcotics, has followed 333 proceedings, with 364 defendants. Has been indicted in the court and are sentenced 148 defendants. For criminal offenses that are related to illegal activity or state employees in the public service, are followed 407 proceedings, with 224 defendants.For offenses against the person, are recorded 2240 proceedings of which 63 for murder. These crimes have led to the deaths of 271 people and injuring 421 persons. For offenses against property and in economic sphere are 5101 registered proceedings of which were convicted 2413 people, while other 1227 trial continues.

\section{Methodology and Research Goal}

For theft of property, are recorded 2693 proceedings which have been sent to trial and are tried and convicted 1,198 defendants, while the other 653 are judging. For crimes in the field of customs and for criminal offenses relating to taxes are recorded 206 proceedings and are sentenced 145 defendants 62 others are on trial (OSCE Albania Report 2009).International and national studies show that corruption in the Albanian judicial system is perceived to be too high and be a serious obstacle to the functioning of the judicial system. While the new government has demonstrated a serious commitment to the fight against corruption, few concrete measures have been taken so far to tackle the issue of corruption in the judicial system.

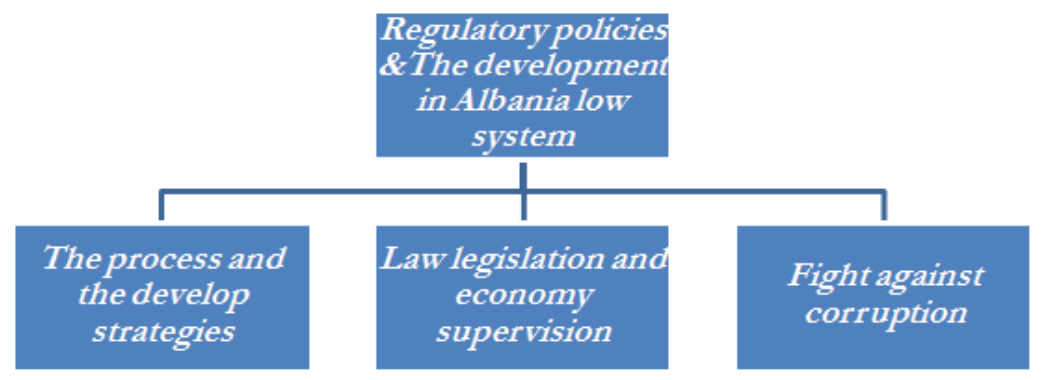

Source: Cumming, C. M., and B. J. HIRTLE (2001): "The Challenges of Risk Management in Diversified Financial Companies, pp 134

To find solutions related to the real and perceived corruption within the system of justice should take measures set. The first step would be to end immediately contacts / inappropriate connections between members of the judiciary and the parties in the proceedings or their representatives. In addition, each court and the prosecution should be required to 
develop strategies and take concrete measures to combat corruption within the relevant institution in the Republic of Albania.

\subsection{Needs for legal proceedings rigorous in Albanian system?}

As noted in this scientific work, deprivation of liberty of persons sets it in an extremely delicate situation. For this reason, it is important that the deprivation of liberty to be as limited and to follow rigorous proceedings defined in international documents, the Constitution of the Republic of Albania and in the Code of Criminal Procedure. All actors involved, that are police, prosecutor, judge and defense attorney, also have a key role in maintaining these standards and in taking action against abuses against persons or investigative actions.

In this aspect, there is room for much improvement in the Albanian context. Thus, it is observed that in most cases, persons deprived of their liberty are not informed of the reasons for arrest or their rights; them regularly abused by the police; they are unable to contact with a lawyer and are not sent before a judge within the time specified in Constitution. Decisions argued in a poor manner and give the impression that decisions on the appointment of security measures often issued without legal reasons.

\subsection{Economic criminality prevention based on EU Convention}

Considering the fact that economic criminality can appear in different forms, according to the recommendations contained in the International Convention, but also in bilateral agreements for the elimination of economic criminality, is necessary that within each system to be established more bodies and specialized institutions in order to be able to follow, detected and sanctioned this type of criminality. Anti-corruption policy is in the foreground, not only in the transition period, but also in other developed countries, because it is a widespread international phenomenon and socially very great risk. The fight against corruption, as international phenomenon, requires not only an effective policy within the country, but also international cooperation, based on the European Convention.

From criminal and legal standpoint, figures analyzed in the special part of criminal law and practice will prove how that it would be effective measures taken to prevent and fighting corruption at the present time and which areas will need to be met, in order to fight his policies give proper results. Important role in economic crime prevention directly have; courts, public prosecutors, police, financial police and customs and services indirectly, the management of public revenues, directorate for prevention of money laundering, the state anti-corruption commission, , the state market inspectorate etc..

\section{Conclusions and recommendations}

Economic criminality undoubtedly now considered as very dangerous form that hurting the economies of countries, be developed or under development. Important role in economic criminality prevention directly have; courts, public prosecutors, police, financial police and customs services and indirectly, department of public revenue, directorate for prevention of money laundering, the state anti-corruption commission, the state market inspectorate etc. The challenges facing the Eurozone together with the recent global financial crisis have highlighted the interdependence of national economies both within and beyond the EU. They underline the importance of further consolidating economic and financial stability and fostering reforms and growth, also in the enlargement countries. The enlargement process is a powerful tool to that end

Also the implementation of the legislation has a special significance in the prevention and combating of successful economic criminality.

In preventing and combating economic criminality, important contribution will also provide ongoing scientific approaches, various economic forums, seminars, national and international conferences, etc. Crimes in the field of customs and for criminal offenses relating to taxes and tax liabilities are recorded 206 proceedings, with almost the same figure in 2002. Have been tried and convicted 145 defendants and are in judicial review 62 defendants. Analysis of the number of prosecutions for these offenses shows 21.7 percent of proceedings for crimes in the field of customs. Downward trend in 57 percent of proceedings for criminal offenses in connection with taxes and tax liabilities, does not reflect the real state of criminality in this important area, where collected revenues for the state budget. "Continues to feel the lack of effectiveness of internal control in taxes and tax liabilities, and therefore is not detected and reported the real criminality in this sector, which has to do not only with the concealment of income, but also with the laundering of dirty 
money.

Strengthening the rule of law and democratic governance is central to the enlargement process. With the Council's endorsement of the Commission's proposed new approach to negotiations on judiciary and fundamental rights and on justice, freedom and security, the rule of law, including common challenges such as the fight against organised crime and corruption, is firmly anchored at the heart of enlargement policy. Accession negotiations on these chapters will be opened early in the process and closed at the end to allow maximum time for solid track records to be developed with the aim of irreversibility of reforms.

\section{References}

Penal Code of the Republic of Macedonia; Publish 2000 year

Penal Code of the Republic of Albania; Publish 1999 year

A. Dumi, General knowledge of the economy and ADP, Publish January 2012,

A Dumi, MJSS Journal 2012 Vol 3 Nr 3 "Albania and Development low"

A Dumi, ICLITM September 2012 Vol 2 Tomas and Royter Publish ISBN 987-605-60771, pp42

A.Jashari, Commercial law subjects, Tetovo, 2008

I.Zejneli, Criminal law- special part- lectures, Tetovo, 2007

I.Zejneli, Criminal law- special, Tetovo, 2012

R. Halili, Criminology, Pristina, 2009

V.Latifi, Criminology, Pristina, 2008

S.Begeja, Criminology, Tirana, 2004

M.Kancev, Kazneno pravna zastita na ekonomskite odnosi, MPKK, nr.1, Skopje, 1997

Sh.Milan, Organizovani crime-Pojam of krivicnoprocesni aspect, Belgrade, 2003, CPC Article 316.CPC Articles 321 and 322.

4 Justice and Home Affairs Council Conclusions of December 6-7, 2007, Council doc.15966/07, Presse

275, p.21

Convention on the Prevention of Terrorism Art.26(3) stating that "parties which are members of the European Union shall, in their mutual relations, apply Community and European Union rules in so far as there are Community or European Union rules governing the particular subject concerned and applicable to the specific case".

See also the Declaration formulated by the Community and Member States upon the adoption of the Convention, where it is stated that the objective of the insertion of a disconnection clause is to take into account the institutional structure of the Union when acceding to international Conventions.

See comment by Tony McNulty, then a Home Office Minister, to the House of Commons European Scrutiny Committee, 26th Report (session 2007-08), para.26.3.CPC Article 340. Civil Procedure Code, Section $173 \mathrm{dh}$ ).

CPC Article 364 Commentary of Criminal Procedure; Halim Islam, Artan Hoxha and llir Panda, Tirana 2003, p. 489.

Civil Procedure Code, Article 236. CPC Article 341.United Nations Convention on International Organized Crime (Palermo Convention), adopted on 12-15 December 2000.

DNB (2002): "Structure of Financial Supervision," Quarterly Bulletin of de Nederlandsche Bank, March, 37-42. DOWD, K. (1994): "Competitive Banking, Bankers' Clubs, and Bank Regulation," Journal of Money, Credit \& Banking, 26, 289-308.

EC (2001): "Towards an EU Directive on the Prudential Supervision of Financial Conglomerates," Brussels: European Commission.

Edwards, F.R. and M.S. Canter (1995). The Collapse of Metallgesellschaft: Unhedgeable Risks, Poor Hedging Strategy, or Just Bad Luck?, Journal of Applied Corporate Finance 8, 86-105. 